\title{
Transforming Art Education into Visual Culture Education Through Rhizomatic Structures ${ }^{1}$
}

\author{
Paul Duncum \\ University of Illinois, Champaign Urbana \\ pduncum@illinois.edu
}

\begin{abstract}
Believing that art teachers need specific models to transform their classroom practice to include the concept and practice of visual culture, the author offers many examples drawn from available literature as well as his own teaching experience. Many cases of classroom curriculum dealing with popular culture topics are introduced, along with what teachers report as benefits. The author then describes one aspect of his own evolution as a teacher of K-12 art teacher preparation courses in the United States that introduce practical activities related to the superordinate structure of visual culture, which is rhizomatic.
\end{abstract}

Keywords: Art education, Fine arts, Visual culture, Curriculum, Rhizome

\footnotetext{
${ }^{1}$ Paper presented at Anadolu International Symposium on Arts Education, Eskisehir, May 14, 2014
} 


\section{Transforming Art Education into Visual Culture Education Through Rhizomatic Structures}

The focus of this paper is the transformation of art education from an exclusive interest in fine art to embrace the much broader concept of visual culture. Before addressing what this might mean however, I should clarify what I mean by both terms: art and visual culture. By art I refer to those artifacts usually to be experienced in art galleries or art museums. These institutions house both an archive of the past - typically in the from of paintings, sculptures, drawings and limited edition prints - and also new emerging art forms that often seek to challenge and critique dominant values and beliefs or at least to offer alternatives to them.

By visual culture I refer to a very broad range of visual artifacts that include all of the fine arts, past and the present, but also popular culture, typically, television, cinema and computer screens, magazines, newspapers, and billboards; in short, all the visual imagery that today grounds societies in a sense of themselves. This is often called dominant culture (Williams, 1977), first, because there is so much more of it today than any other kind; secondly, because it is closely tied to dominant economic interests; and, third, because it is constitutive of a society's mainstream beliefs and values. This is the primary culture of our students; this is the culture that simultaneously forms and informs their ways of looking at and thinking about the world.

Today, avoiding student's own popular visual culture is no longer a feasible. Studying Monet while students are playing the MineCraft computer game is ridiculously inadequate. Making color wheels and collages to do with line, shape and texture no longer makes any sense while outside school students are producing their own videos and communicating with peers around the world as part of a networked culture. Many teachers appear to recognize this divide, but often do not know how to 
Anadolu Journal of Educational Sciences International, Art Education Special Issue, November 2015

bridge it. Trained to induct students into the mysteries of modernism, or even postmodern art, they find themselves at a loss with student's own popular culture. Although most art teachers enjoy as much popular culture as anyone else, it remains cut off from their classroom practice.

\section{Visual Culture in the Classroom}

Nevertheless, over the past decade or so many art teachers have taken up the challenge of addressing popular visual culture. In doing so they have relied upon a view of culture as semiotic texts, not as high culture wherein artworks are assumed to glow with a quasi-divine aura. Treated as semiotic texts, as signs of meaning rather than carrying the modernist baggage of fine art, pictures are treated as constitutive of social values, beliefs, and conflicts. Pictures are understood as sites of social contestation. This is a socially leveled view of visual culture, one without a predetermined hierarchy of value. For example, employing semiotics, the Mona Lisa is not a work of incomparable artistry but alongside the more recent pop star Madonna, a sign, for example, of what it means to be a woman and/or what it means to be famous.

With this semiotic view of pictures, many art teachers have made inroads into conventional practice, and their experiences are instructive. It is one thing for art education academics to advocate for change; it is another to show how, in the face of all the obstacles to change that teachers face student, administrative and parental expectations; available technologies; and teacher's own knowledge - it is still possible to make changes.

I have previously reviewed many such efforts in both K-12 classes (Duncum, 2007) as well as in teacher preparation classes (Duncum, 2009). Some pre-service programs have considered such cultural sites as Elvis icons, makeover programs, Hollywood films, music videos, theme parks, tourist souvenirs, cosmetic surgery, situation comedies, and even popular representations of traditional Turkish puppet shows. Among the cultural sites that teachers in K-12 schools have 
Anadolu Journal of Educational Sciences International, Art Education Special Issue, November 2015

explored are Disney animated films, the conventions of school portraiture, advertising and magazines for young children, teen magazines, and movies. Through such cultural sites, teachers report dealing with topics like the representation of gender and race; sexuality; disability; cultural hybridity among communities of diaspora; and ideas about childhood, celebrity, and gang violence. Fifth graders have considered drugs, drunkenness, and even credit card abuse. High school students have examined media concentration, sweatshop labor, cyber technology, war, propaganda, and violence towards women.

Teachers reported a variety of successes. These include students showing a greater sense of control in understanding media messages, dealing with students' deeply personal issues, being made aware of students controversial and politically incorrect views that otherwise would have remained concealed, and the opportunity for students to work through their own views and values. Teachers also reported that by engaging students with media representations of personal issues, they learned more about their students than they had ever before. One high school teacher, wrote, "I became a student of my own classroom" (cited in Duncum, 2007, p. 221).

Since my reviews, many other art educators have explored further issues and specific cultural sites. Like my earlier reviews from 2007 and 2009, some of these programs were conducted in elementary classrooms, some with high school students, and some in art teacher programs. The range of cultural sites is extensive, including second life (Han, 2013; Lu, 2010); video games (Gill, 2009); graphic novels (Carpenter \& Tavin, 2012); Argentinian telenovelas (Christopoulou, 2010); Barbie dolls (Amburgy, 2011); on-line image galleries (Carpenter \& Cifuetes, 2011); animated film (Madrid, 2012); shop window displays (Christopoulou, 2011); popular images of the Buddha (Shin, 2010); family snapshots (Baxter, 2012); heritage tourism (Ballengee-Morris \& Sanders, 2009); graffiti, tattoos, and public and private memorial shrines (Bey, 2012); adolescents own webpages (Bae, 
Anadolu Journal of Educational Sciences International, Art Education Special Issue, November 2015

2011); commercial brands (Danker, 2014), Tamagotchi electronic pets (Ivashkevich, 2011); the parody news program The Colbert Report (Derby, 2013); political advertising activism (Briggs, 2013); fan art (Manifold, 2013; Chung, 2011); and advertising and newspaper cartoons (Chang, Lim \& Kim, 2012). For my part, I have recently explored unsolicited youth productions on YouTube (Duncum, 2013). The issues that such sites have raised include media stereotypes of race (Martinez, 2010), sexuality (Chung, 2013), and disability (Seidler, 2011). Additionally, teachers have variously asked students to answer back to such cultural sites using photography, video production, and magazine mockups.

\section{The Structural Transformation of Fine Art to Visual Culture}

Taken together the above range of cultural sites indicate a transformation in art education, site by site and issue by issue. In what follows, I will consider the overarching structural transformation that undergirds what is happening with the introduction of such cultural sites. By dealing here with the superordinate structure of visual culture, I consider what is most foundational to the transformation. The structure of visual culture and a visual culture curriculum is rhizomatic. I will begin by describing the nature of rhizomes, and then I will describe some of my own classroom activities by which I have sought to illustrate how visual culture operates as a rhizome.

The word rhizome is Greek in origin. It refers to a mass of roots, usually underground that typically sends out shoots from its nodes. Grass and ginger are common examples, as are animal burrows and animals that operate in packs likes rats and ants. Deleuze and Guattari (1987) famously extended this biological structure to thinking about the world in general, and it is useful to consider the distinction they make between rhizomes and trees, because the distinction is easily mapped over a conventional modernist art education curriculum and a postmodern, visual culture curriculum. 
The modernist curriculum is like a tree with a trunk, roots and branches, where the common factor between the roots and branches is the trunk. The trunk represents foundational knowledge, the core of the curriculum, typically the elements and principles and the particular qualities of materials. The roots of the tree represent the histories of art, which fortunately today often includes more than the modernist, linear history of stylistic developments that begin with cave art and is then traced with major stops in Athens, Rome, Florence, and Paris, to end up in the New York of the 1950s. References to Asia, Africa, Australasia, and the Middle East are now often included, as is the art of women and other previously marginalized groups. The branches of the tree represent all the issues art deals with; for example, gender relations, race, sexuality, patriotism, heroism, natural beauty, violence, horror, human passions, and so on.

There are several crucial problems with this modernist, tree-like curriculum that are both theoretical and practical. First, in practice, teachers who operate with little time and opportunity in school are often unable to teach much beyond what this modernist model of curriculum considers core knowledge. Second, if teachers find the time to consider art history, since the core is conceived in formal terms of line, color, composition and the qualities of materials, and not ideas, values and beliefs, art historical images are consequently considered primarily, or even exclusively, in formalist and materialist terms. Third, strapped for time, teachers are frequently unable to consider the ideas, values and beliefs with which art deals and has always been the primary motivation for making art in the first place as well as for many viewers the primary interest of art. Forth, the model is especially susceptible from attack. As strong and as long-standing as trees can be, they are highly vulnerable to an axe. Similarly, with the suggestion that the formal elements and principles, or the particular quality of a medium, are no more the core of art than many other considerations, it can 
Anadolu Journal of Educational Sciences International, Art Education Special Issue, November 2015

seem as though art itself is destroyed. And this is precisely what postmodern art theory and practice asserts: there is no core to art.

Postmodern theory and practice historicizes the elements and principles as pertaining to just one moment in the history of art, a very brief moment, and one moreover that is now long past. (I should add, a moment that was also always misunderstood because formalism was driven by powerful socioeconomic forces; it was never only about form). Postmodern theory and practice rejects the idea of undisputed foundational knowledge, of a definitive core that in curriculum terms must be understood before proceeding further, a curriculum based on a lock-step progression from simple to complex knowledge, core to peripheral, essential to elective.

By contrast, postmodern theory conceptualizes knowledge as rhizomatic where knowledge is like grass, like ginger, like packs of animals, but also like the Internet and most significant of all, like the way human brains are interconnected. This most complex rhizome of the known universe enables us to associate one idea with another, one image with another, an idea with an image, an image with a song, a song with a memory, a memory with a movie, a movie with a poem, and so on and on. As Deleuze and Guattari (1987) write, "Unlike trees or their roots, the rhizome connects any point to any other point and its traits are not necessarily linked to the traits of the same nature: it brings into play different regimes of signs and even non signs" (p. 21). Any point of a rhizome can be connected to any other point. With rhizomes there is no unity to serve as a pivot, no universal defining reference point. Always there is more, a hallmark of rhizomes being multiplicity and heterogeneity. Think of a musical performance of the same piece; every one is slightly different from every other. Deleuze and Guattari put it like this: whereas "the tree imposes the verb 'to be' the fabric of the rhizome is the conjunction 'and... and...and..." (p 25). 
Anadolu Journal of Educational Sciences International, Art Education Special Issue, November 2015

Furthermore, different from trees that are susceptible to easy destruction, a rhizome is exceptionally difficult to destroy. Deleuze and Guattari write,

A rhizome can be broken, shattered at a given spot, but it will start up again on one of its old lines or a new line. You can never get rid of ants because they form an animal rhizome that can rebound time and again after most of it has been destroyed. (p. 9)

This applies equally to human social life where for example centers of power are destroyed but are later reconstituted. As Deleuze and Guattari (1987), write, "Groups and individuals contain microfascisms just waiting to crystallize" (pp. 9-10).

Rhizomes have multiple entry and exit points, and each time one enters the journey is likely to be different. "A rhizome has no beginning or end; it is always in the middle, between things, interbeing, intermezzo" (p. 25). With their multiple entry and exist points, one travels though rhizomes by coming and going rather than beginning and ending, for there are no ends to rhizomes (p. 25). One navigates a rhizome as a nomad, wondering without a predetermined destination or goal; it is the journey that must count, not the end state, for every apparent end state leads onto other issues and still others.

Visual culture is rhizomatic in structure; it too spread laterally, connected by multiple, layered references; and it too offers multiple entry and exit points in both representation and interpretation. An image draws upon numerous references and, in turn, every individual act of viewing conjures up any number of associations. Thus does visual culture possess no core, no basic principles from which one must begin before proceeding further. It does not operate under any kind of central control. It operates as Deleuze and Guattari (1987) claim, by “ceaselessly established connections between semiotic chains, organizations of power, and circumstances relative to the arts, sciences, and social struggles" (p. 7). As a rhizome visual culture spreads like oil on the surface of a body of 
Anadolu Journal of Educational Sciences International, Art Education Special Issue, November 2015

water, potentially spreading everywhere and connecting to everything. Thus, today popular culture draws upon the fine art of the past, as well as its connections to politics, economics, and social formations, including struggles over gender, race, class, nationalism, war, the environment, poverty, consumerism - all the isms and ideologies of which social life is composed.

\section{My Classroom Practice}

To help realize these numerous connections, I have followed the practice of some other art educators (Carpenter \& Taylor, 2006; Herrmann, 2006; Tavin, 2002; Taylor, 2000; Taylor \& Carpenter, 2003, Wilson, 2000) in developing ways to encourage associative thinking and in the process to demonstrate to my students that the way they live their lives and their professional interests in the history of and contemporary practice of art can be intertwined. Below, I describe just two exercises I do with my pre-service art teachers that demonstrate the rhizomatic nature of visual culture.

\section{Hyperlinked PowerPoint Rhizomes}

Rhizomes have no beginning or end, but of course an organized, timetabled curriculum must have both. We must therefore start somewhere, yet we could start anywhere; for example, with an image, an idea, a definition, song lyrics, a philosophical position, an issue, or a controversy.

Some years ago I had students start with an image of their choice and with the instruction to consider it in terms of three or four themes, suggesting that the themes should appear to arise from the image. I used to begin by ensuring that the image students chose was of sufficient richness to enable them to generate such associative connections, but I soon found that almost any image has this potential.

I had students create an electronic rhizomatic site using the hyperlink facility on PowerPoint. Some other programs facilitate a rhizomatic structure far better - Powerpoint being essentially an old 
Anadolu Journal of Educational Sciences International, Art Education Special Issue, November 2015

fashioned, linear slide show - but since the program appears on all computers economics trumped the ideal.

Originally, I had students work individually. Examples of images the students chose to work from include an eclectic mix of popular and fine art examples: Michelangelo's Pieta; Andy Warhol's 1967 silk screen Electric Chair; John Lennon's Memorial in New York; A Norman Rockwell illustration; various advertisements including one for the clothing retail chain The Gap; a movie poster for the 1939 Gone with The Wind; posters for the Walt Disney animated films Fantasia and Tarzan from respectively; a Wonder Woman comic cover; the television program Mean Girls; and photograph of the comedian known as Borat.

To illustrate how such images were able to set off a chain of associations I offer just one examples. The student chose of photograph of the Olsen twins, Ashley and Kate, who gained fame initially through appearing in the television program Full House but went onto appear in over 40 movies, release multiple music albums, to author a best-selling book, and to have their own clothing line, hair products, dolls, and a magazine. They were iconic consumer-driven celebrities, and all by the time they were in their early 20 s.

The photograph was linked to the primary themes of twins, family values, and eating disorders. Twins was linked to many different kinds of twins, including people, as animals and things, as well as the astrological sign of Gemini; that linked to sculptures from Egypt and Africa; that was aligned with sisters, including the student's own sister; several celebrity sisters other than the Olsen twins; which were connected to images of friendship. Family values was linked to the television show that stared the Olsen twins, which was linked to families on U.S. television in each decade from the 1950s to the 2000s. The student also linked to her own Italian family, which she linked to Italian Renaissance paintings of families, that linked to happy families, that was illustrated with Martel's 
Anadolu Journal of Educational Sciences International, Art Education Special Issue, November 2015

marketing of their happy family toy series and viewed by the student as stereotypically American. Simultaneously, her Italian family was linked to families in other cultures, specifically Chinese and Hispanic families. And for the sake of brevity, I have not even mentioned eating disorders.

\section{Paper, Pin and Yarn Intertexts}

More recently I have employed a low-tech approach and involved the whole class in the production of an intertext using paper, push pins, woolen yard and a large pin board. I begin with a brainstorming exercise. Using a variety of images, fine art and popular art, I have students generate a list of associations and then create a rhizomatic map with as many connections as they can establish. I usually hover about making my own suggestions, often to art history. For example, with a movie poster of The Hulk, I suggested examining Michelangelo's fresco of his massively muscular Christ from the Last Judgment alongside the monumentality of totalitarian sculpture, for by similar means they served similar functions.

I then ask students what is "hot"? What is catching their attention right now? With each class this is different, and often I have never heard of the cultural sites they mention. Because this is to be a whole class activity, I list their suggestions and we then vote. Once a site is established, I ask what the site references, list their references, and then assign individuals or pairs to research their suggested references. Some students are then tasked to find definitions, others to find contemporary visual examples, and others still to find historical visual examples. Some students find relevant poems or song lyrics, and some students write up their own responses.

Examples of cultural sites that have won the vote, and which we subsequently explored have included the television situation comedy Gossip Girls and the television talent program American Idol. Gossip Girls allowed students to explore visual representations of celebrity, gossip, scandal social class, childhood, and family, and they further broke down family into poor, wealthy, nuclear, 
Anadolu Journal of Educational Sciences International, Art Education Special Issue, November 2015

extended, and single-parent. Starting with American Idol allowed students to explore the concepts of celebrity, romance, love, relationships, work, family, comedy, the carnivalesque, and rags to riches stories.

A recent class chose the pop singer Miley Cyrus. Since she is a former Disney child star one of the links was to other child stars, and this generated a discussion about prodigies and what so often happens to them - burning out or going on to have troubled lives. This discussion morphed into a discussion about the nature of childhood: innocent, evil, victims, abused, sexualized, studious, consumers? Another link was to scandal. As a child star Cyrus had embodied the ideology of childhood innocence, but her actions as a late teen/young adult were controversial. We discussed different kinds of scandals; for example, sexual, political corruption, and cheating in sports, and we asked which was worse and why? Cyrus had scandalized fans and commentators alike with highly sexual performances, especially the dance known as tweeking. Was she being exploited, was she exploiting her audience, or was she, as she claimed in interviews, to be expressing her own empowerment? This current media debate not only reworks the divide between second and third wave feminist theory of the 1980s and 1990s, but also divided my own students in 2014 . We linked her infamous performance to what the students called other over the top performances and specifically to dancing and to making a distinction between Anglo-American dancing and Africaninspired dancing; that is, between using only the upper part of the body versus using the whole body. I was able to contextualize this distinction by referring to the controversy African dance styles caused in early America as well as the age-old distinction between Apollonian restraint and Dionysian release, between order and alleged chaos and unreason. And it was small step to noting that this distinction has often been used to marginalize people, in particular the young, women, people of color and non-Westerners. Cyrus's transformation from innocent to sexually aware was 
Anadolu Journal of Educational Sciences International, Art Education Special Issue, November 2015

also linked to the more general idea of transformation and metamorphous, which the students readily linked to drugs. For my part I took the opportunity to talk about how children's unsolicited drawing often deals with the theme of metamorphous, a not surprising theme given the fact that children are themselves continually undergoing bodily transformations. Since Cyrus has a tattoo students also linked her to bodily decoration, and we then talked about how different forms of body decoration was practiced by indigenous peoples all over the world. I mentioned that not only had the earliest humans been tattooed, but that bodily decoration has come to be one of the major forms of asserting identity in our highly rationalized societies where the body remains one site over which people still retain control.

In this way, we were able to discuss many themes, current trends, and age-old human practices. And all this proved possible by treating one contemporary celebrity pop star as an intersection of many competing ideas, beliefs and values. And always at the conclusion of these rhizomatic activities, whether using a computer program or just pins, paper and yarn, student see that the rhizome they created could be extended to include further issues, to continue indefinitely.

\section{Coping with Endless Multiplicity}

However, one of the concerns student-teachers often raise is: If visual culture is rhizomatic, how can we to cope with its complexity? Additionally, how is it possible to deal with visual culture when so much of it is ephemeral, when what is hot one year is replaced the next by something equally only of the moment? Student-teachers ask, when it is always Monday morning in schools, where are we to get the time to prepare and collect resources? It seems to them so much easier to deal with well-established content like the well trod history of fine art.

These are legitimate questions; and there is no point in academics devising theoretical models that cannot be translated in practical terms. Fortunately, I think there is a solution, one proposed by one 
Anadolu Journal of Educational Sciences International, Art Education Special Issue, November 2015

of my teaching assistants. ${ }^{1} \mathrm{He}$ made the point that whatever cultural site a class proposed it was likely to involve certain themes which would emerge repeatedly. The usual suspects would be gender roles; class, and race, but often there would be other likely topics such as those I have mentioned above. This is partly because of the society in which we now live and partly due to the students own demographic. My students chose particular cultural forms because they dealt with a range of themes that were especially important to them. It was not an accident that issues like family, childhood, consumerism, and celebrity emerged again and again. This would be true of any student demographic so that over time a teacher could develop curriculum - with aims and objectives, resources, activities and assessment criteria - for each of the topics that repeatedly emerged as if spontaneously. Given their choice of a starting point, each class would almost invariably choose a different cultural site, but teachers could channel the themes to be explored to those for which they had already prepared.

\section{Conclusion}

There are many ways to begin the transformation of art education into visual culture education. In this paper I have described some of the particular cultural sites that K-12 teachers and teacher educators have employed in their classrooms. But to fully grasp this transformation it is necessary to understand the nature of visual culture as rhizomatic, as intertextual, as one image links to numerous others past and present, to other cultural forms and always embedded in social preoccupations, anxious certainties, fears, hopes and desires. Starting from a single image and moving laterally, visual culture connects with many forms of representation, past and present, across cultures, in a variety of media, and manifesting a huge range of issues in either support of, resistant to, or alternative to, mainstream contemporary life. Above all it is important to grasp the transformation to visual culture as linking to students own lives. 


\section{References}

Amburgy, P. M. (2010). Diversity, pedagogy and visual culture. Art Education, 64(50), 6-11.

Bae, M. (2011). Interrogating girl power: Girlhood, popular media and postfeminism. Visual Arts Research, 37(2), 28-40.

Ballengee-Morris, C., \& Sanders, J. H. (2009). Culture, identity, representation: The economic policies of cultural heritage. International Journal of Education Through Art, 5(2\&3), 129-142.

Baxter, K. (2012). The role of family snapshots in teaching art history within a dialogic pedagogy. Art Education, 65(1), 11- 19.

Bey, S. (2012). Engaging 'gangland' visual culture: Memorializing Beltzhoover's victim of violence. Studies in Art Education, 53(2), 94-111.

Briggs, J. (2013). Eric Garcia: Warrior with a pen. Art Education,66(6), 47-54.

Carpenter, S., \& Tavin, K. (Ed.) (2012). Special issue: The Graphic novel and art education. Visual Arts Research, 38(1).

Carpenter, B. S. \& Cifuentes, L. (2011). Visual culture and literacy online: Image galleries as sites of learning. Art Education, 64(40, 33-40.

Carpenter, B. S., \& Taylor, P. G. (2003). Racing thoughts: Altering our ways of knowing and being through computer hypertext. Studies in Art Education, 45(1), 40-55.

Chang, E., Lim, M., \& Kim, M. (2012). Three approaches to teaching art methods courses: Child art, visual culture, and issues based art education. Art Education, 65(3), 17-24. 
Anadolu Journal of Educational Sciences International, Art Education Special Issue, November 2015

Christopoulou, M. (2010). Telenovelas as art curriculum content. Art Education, 63(4), 19-24.

Christopoulou, M. (2011). Exploring shop window displays. Art Education, 64(3), 2532.

Chung, S. K. (2013). Critical visual literacy. The International Journal of Arts Education, 11(2), 1-36.

Chung, Y. L. (2011). Group creativity in the popular visual culture of Asian ethnic groups. A model for art education. Australian Art Education, 34(2), 119-136.

Danker, S. (2014). Brand: Identity, image, and relationships. Art Education, 67(1), 4151.

Derby, J. (2013). The truthiness about The Colbert Report. Art Education,66(6), 40-45.

Duncum, P. (2007) What we are learning about teaching popular visual culture. In J. A. Park (Ed.), Art education as critical inquiry (pp. 216-233). Seoul, Korea: Mijinsa.

Duncum, P. (2009). Visual culture in art education, Circa 2009. Visual Arts Research, 35(1), $64-75$.

Duncum, P. (2013). Creativity as conversation in the interactive audience culture of YouTube. Visual Inquiry: Learning and Teaching, 2(2), 115-125.

Gill, D. V. (2009). Usefulness of video game experience for student learning and creating digital 3-D. Visual Arts Research, 35(2), 109-121.

Deleuze, G., \& Guattari, F. (1987). A thousand plateaus. (B. Massumi, Trans.). Minneapolis, MN: University of Minnesota Press.

Han. H. C. (2013). The third culture: Virtual world visual culture in education. The Journal of Arts Education, 11(20, 37-74 
Anadolu Journal of Educational Sciences International, Art Education Special Issue, November 2015

Hermann, R. (2006). In the classroom with ducks, swans, and elementary education majors. In P. Duncum (Ed.), Visual Culture in the Art Class: Case Studies (pp.142150). Reston, VA: National Art Education Association.

Ivashkevich, (2011). Girl power: Postmodern girlhood lived and represented. Visual Arts Research, 37(2), 14-27.

Lu, L. (2010). Teaching $21^{\text {st }}$ century art education in a virtual age: Art Café@Second Life. Art Education, 63(6), 19-24.

Madrid, M. (2012). Paradox in a/r/tography: Collective short animated film making for social inclusion. Visual Arts Research, 38(2), 58-68.

Manifold, M. (2013). Enchanting tales and imagic stories: The educational benefits of fan art making. Art Education,66(6), 12-19.

Martinez, U. (2012). Cultur(ally) jammed: Culture jams as a form of culturally responsive teaching. Art Education, 65(5), 12-17.

Seidler, C. O. (2011). Fighting disability stereotypes with comics: "I cannot see you but I know you are staring at me. Art Education, 64(6), 20-23.

Shin, R. (2010), Why does the Buddha laugh? Exploring ethnic visual culture. Art Education, 63(3), 33-39.

Sweeny, R. W. (2009). There's no "I" in YouTube: Social media, networked identity and art education. International Journal of Education Through Art, 5(2\&3), 201-212.

Tavin, K. (2002). Engaging advertisements: Looking for meaning in and through art education. Visual Arts Research,28(2), 38-47. 
Anadolu Journal of Educational Sciences International, Art Education Special Issue, November 2015

Taylor, P. \& Carpenter, S. (2002). Inventive linking: Teaching and learning with computer hypertext. Art Education, 55(4), 6-11.

Taylor, P. (2000). Madonna and hypertext: Liberatory learning in art education. Studies in Art Education, 41(4), 376-389.

Wilson, M. (2000). The text, the intertext, and the hypertext: The story. Proceedings of the Art Education and Visual Culture Conference (pp. 89-124). Taipei Municipal Teachers College, Taipei, Taiwan.

Williams, R. (1977). Marxism and literature. Oxford, England: Oxford University Press.

\section{Footnote}

${ }^{1}$ Brad Olson 